\title{
Uzay Fotogrametrisi
}

\author{
Erol UYSAL* Selçuk Üniversitesi, Mühendislik Fakültesi, Konya, Türkiye, \\ euysal@ selcuk.edu.tr
}

\begin{abstract}
Özet
Yeryüzüne ait konumsal bilgiler elde etmede uydu görüntüleri, teknolojik gelişmeler doğrultusunda geçmişe nazaran daha kullanılır ve pratik olmaya başlamıştır. Yüksek çözünürlüklü uydu görüntülerinin erişmiş olduğu bu üstün kalite bu verilerin ortofoto görüntüler ve diğer haritacıllk ürünleri konusunda iyi bir kaynak olabileceği literatürde iyice yer edinmiştir. Şüphesiz bunun en önemli nedeni elde edilen görüntülerin yer örnekleme aralığının (GSD) küçülmesi yani çözünürlüğün artması ve bu sayede nesneler daha ayrıntılı olarak elde edilmektedir. GSD' nin yanı sıra görüntülerin radyometrik ve tayfsal çözünürlüklerin kullanılan bantlar aracıllğıyla birlikte veri içeriğini etkilemektedir. Böylelikle elde edilecek sonuç ürünlerin istenilen özelliklerde olması ihtiyaca gore üretim sağlanmaktadır. Bu çalışmanın amacı, teknolojinin ilerlemesiyle uzay fotogrametrisinin ve uzaktan algılamanın fotogrametrik ürünler elde etmede ve dünya üzerinde var olan sorunlarda çözüm üretme potansiyelini araştırmak ve uygulanabilirliğini ele almaktır.
\end{abstract}

Anahtar Kelimeler: Algılayıcılar, Fotogrametri, Metre-alt, Uydu Görüntüleri, Uzay Fotogrametrisi, Uzaktan Algılama, Yüksek Çözünürlük

\section{GíRiş}

Çizilmiş olan ilk haritalar genellikle yeni keşifler sonucu ya da ilgili bilim adamlarının gerçekleştirdikleri seyahatler sonucu ortaya çıkmıştır. Yapılmış olan keşifler ve seyahatlerin sayesinde çizilen haritalar yardımıyla aynı zamanda yeni uygarlıkların kurulmasına da ön ayak olmuştur.

Osmanlı İmparatorluğu döneminde Lagari Hasan Çelebi'nin gerçekleştirmiş olduğu insanlı roket denemesi uzaktan algilama alanında araç ve gereçlerin yapay olarak kullanılmasının ilk örneğidir. Bundan dolayı ilk olarak insanlı uzay denemesinin biz Türkler tarafından gerçekleştirildiği kabul edilmektedir (Önder, 1999).

Fotoğraf ve uçağın sirasıyla 1839 ve 1903 yıllarında keşfi sayesinde hava fotoğrafı alımının gerçekleştirilmesi 1910 yılından itibaren sağlanması ile klasik haritacılık sektörü yeni bir boyut kazanmıştır. Kuşkusuz büyük bir dönüm noktası olarak görülen olay Alman Mühendis Alfred Maul' ün 1912 yılında görüntü alım amaçlı geliştirdiği 41 kg' lık ağırlığa sahip, kamera entegre edilmiş ilk uydunun $700 \mathrm{~m}$ yüksekliğe firlatılmasıdır (Önder, 1999).

Uzayda gerçek anlamda uzaktan algılama New Mexico' dan 1946- 1950 yılları arasında firlatılmış olan V-2 roketlerine entegre edilmiş küçük kameraların (K-12) kullanılması ile başlamıştır. Uydulardan elde edilmiş görüntüler günümüzde; hidroloji, meteoroloji, oşinografi, jeoloji, ormanc1lık, bitki örtüsü, topoğrafik harita üretimi, DTM (Sayısal Arazi Modeli), DEM (Sayısal Yükseklik Modeli) ve DSM (Sayısal Yüzey 
Modeli) üretimi, bölgesel planlama, şehir planlama, arazi kullanımı, toprak ve zemin etüdü, hava tahmini, ürün tespiti, çevre kirliliklerinin araştırılması, istihbarat ve savaş vb. alanlarda kullanım alanı bulmuştur (Önder, 1999).

İlerleyen y1llarda meteoroloji, deniz ve okyanus araştırmaları, kutuplar ve buzulların incelenmesi, yeryüzünün araştırılması ve haritacılık çalışmaları için çeşitli ülkeler çok sayıda uzaya uydu göndermiştir. Illk etapta düşük doğruluk ve çözünürlük elde edilmiş olan uydu görüntüleri süreç içerisinde iyileştirilmiş ve önemli aşamalar kaydedilmiştir. Son yıllarda yüksek çözünürlüklü uydu görüntülerinin erişmiş olduğu seviye düşünüldüğünde ortofoto görüntülerin haritacılık alanında iyi bir veri kaynağ ${ }_{1} \quad$ olabileceği gerçekleştirilen çalışmalarla tespit edilmiştir. Özellikle siyasi sınırlamalar ve dönemin koşullarından dolayı hava fotoğrafi alımın güç ekonomik olarak zor olduğu durumlarda çok iyi bir alternatif olmakta ve etkili bir şekilde kullanılabilmektedir (Li ve diğ., 2000).

Fotogrametri, ISPRS (International Society for Photogrammetry and Remote Sensing)' in tanımına göre; "fotografik görüntülerin ve elektromanyetik enerjinin kayıt, ölçme ve yorumlanması sonucu fiziksel cisimler ve bunların çevresine ilişkin bilgileri oluşturan ve bu bilgilerin analizini yapan bir bilim dalıdır." (URL 1).

Fotogrametri, resim çekim yerlerine göre;

- Hava fotogrametrisi

- Yersel fotogrametri

- Uydu fotogrametrisi fotogrametrisi)

(Uzay

Olarak üçe ayrılır (Gürbüz, 2006).

Uzaktan algilama, ASPRS (American Society for Photogrammetry and Remote Sensing)' in kabul ettiği tanıma göre; "fiziksel nesneler ve çevre hakkında, nesnelerle ve çevreyle teması olmayan algilayıc1 sistemlerle elde edilen görüntü ve enerji desenlerinin sayısal gösterimden ölçülerek veya yorumlayarak güvenilir bilgi elde etme sanatı, bilim ve teknolojisidir" (URL 2). Uzaktan algılamanın temel çalışma prensibi yeryüzündeki nesnelerden yansiyan elektromanyetik enerjinin uydu sensörleri aracılığıyla algilanmas1 ve nesnelerden elde edilen verilerin analiz edilmesidir. Yeryüzü hakkında hızlı ve doğru bilgiye olan ihtiyacın gün geçtikçe daha da artması hızlı nüfus artış1, giderek kısıtlı hale gelen doğal kaynaklar, çevre kirlilikleri gibi nedenlerden dolayıdır. $\mathrm{Bu}$ durum da günümüzde modern teknolojik donanıma sahip, son yıllarda kullanım alanları ve kullanıc1 sayısı artmış olan uydu teknolojilerinin kullanımını oldukça cazip hale getirmiştir. Günümüzde yeryüzünün topoğrafyası hakkındaki birçok bilgi, uzaktan algilama teknikleri ile elde edilmektedir. $\mathrm{Bu}$ tekniğin temel veri kaynakları uydu görüntüleridir. $\mathrm{Bu}$ teknolojik gelişmeler sayesinde oldukça geniş alanların görüntüleri elde edilebilmekte istenilen sonuç ürüne bu görüntüler aracılığıyla ulaşılabilmektedir. Bu sayede daha ekonomik ve güncel veriye erişilebilmektedir.

Hiç şüphesiz teknolojinin gelişmesiyle stereo uydu görüntülerini elde etmek amaciyla uzaya uydu gönderen ve bunları web adresleri üzerinden pazarlayan, veri paylaşımından bulunan ticari kuruluşların başında Space Imaging, DigitalGlobe, GeoEye gibi firmalar gelmektedir. Bu firmalardan DigitalGlobe ve GeoEye 1, Ocak 2013 yılında birleşmiş ve DigitalGlobe adı altında hizmete devam etmektedir. Anılan ticari kuruluşların yanı sıra NASA/ABD, CNES/ Fransa, DLR / Almanya, ESA / Avrupa gibi ülkelerin uzaya yönelik araştırma faaliyetlerini yürüten kuruluşlar da bulunmaktadır.

Ülkemizde yapılan uzay çalışmalarıyla ilgili kısa bir bilgi verecek olursak, ilki 1994 yılında gönderilmiş olan TÜRKSAT $1 \mathrm{~B}$ ve devamı olan 1C, 2A, 3A ve $4 \mathrm{~A}$ uydularının tedarik edilmesi ile başlamıştır. TÜBITAK UZAY' 1n, İngiltere' nin SSTL (Surrey Satellite Technology Limited) BILLSAT ve akabinde Türk Mühendislerce tasarlanıp geliştirilen, 2011 yılında uzaya firlattığı RASAT elektro- optik gözlem uyduları bulunmaktadır. TUSAŞ ve Thales Alenia Space' in birlikte özgün olarak geliştirip ürettiği, 2016 yılında TSK' nın hizmetine sunduğu yüksek çözünürlüklü, $\quad 0.50 \mathrm{~m}$ 
çözünürlüğe kadar görüş yeteneğine sahip GÖKTÜRK-1 uydusu Türkiye' nin uydu çalışmaları açısından önemli bir mihenk taşı olmuştur (URL 3).

$\mathrm{Bu}$ bağlamda seminer çalışmamızın hedefi metre alt1 çözünürlüğe sahip yüksek çözünürlüklü uyduların fotogrametri açısından dünya literatüründe var olan bilgilerin teorik olarak ele alınmasıdır. Çalışmanın giriş bölümünde fotogrametrinin fotoğrafın icadı ile başlayan tarihsel süreci süregelen teknolojik gelişmeler ile uzaktan algılama ve uzay (uydu) fotogrametrisi açısından anlatılmıştır. Daha sonraki bölümlerde uydu görüntüleri ve incelenmiş olan metre altı çözünürlüğe sahip uydular anlatılmıştır.

\section{UYDU GÖRÜNTÜLERİ}

\section{Genel}

Uydu görüntüleri piksellerden oluşur. Uydu görüntüleri, algılayıcılar sayesinde sayısal (dijital) olarak elde edilir. Bu algılayıcıların (sensörler) çalışma prensibi dijital kameraların çalışma prensibi ile hemen hemen aynıdır. Sayısal kameralarda olduğu gibi bir uydu algılayıcısı da filme sahip değildir. Filmler yerine algılayıcı yeryüzünden veya uzaydaki objelerden yansıyan elektromanyetik enerjinin miktarını ölçen binlerce küçük alıcilardan oluşmuştur. Bunlar bantsal (spektral) ölçümler olarak isimlendirilir. Her bir spektral yansıma değerinin sayısal bir numara karşılığı vardır. $\mathrm{Bu}$ sayılar bilgisayarlar tarafindan renkler ve gri renk tonlamasındaki parlaklık değerlerine göre fotoğrafa benzeyecek şekilde görüntüye dönüştürülür (URL 3).

\section{Neden Uydu Görüntüleri Kullanılmalı}

Hava fotoğrafi, halihazır haritalar gibi veri kaynaklarının yanında uydu görüntüleri daha ucuz, daha güncel, daha hizlı ve daha pratiktir. Uydu görüntülerinin diğer avantajları ise şunlardır;

- Sayisaldir

- Hizlidir

- Ucuzdur
- $\quad \underline{\text { Evrenseldir }}$

- Günce 1 di r

- Ayr $1 \mathrm{nt} 1 \mathrm{l}_{1 \mathrm{~d} 1 \mathrm{r}}$

\subsection{Uydu Görüntülerine Ait Bazı Tanımlar}

Pankromatik Görüntü (Panchromatic Image): $\mathrm{Bu}$ görüntüler, elektromanyetik spektrumun geniş bir bölümüne ait yansıyan enerjinin algilanması ile elde edilmektedir. Pankromatik algılayıcılarının bant aralığ görünür bölüm ile yakın kızılötesini kapsamaktadır ve bu veriler siyah-beyaz olarak sunulmaktadır.

Çok Bantlı Görüntü (Multispektral Image): Elektromanyetik spektrumun birden çok bantlarında toplanan yansıma değerlerinden oluşan görüntülerdir. İki ayrı algılayıc1, aynı dalga boyunun değişik parçalarına ait enerjiyi ölçebilmektedir. Bu şekilde toplanan birden fazla yansıma değeri renkli görüntü elde etmek için birleştirilmektedir. Halen kullanılmakta olan çok bantlı algılayıcılar, bir seferde üç ile yedi bant arasında yansıma değerini ölçebilme yeteneğine sahiptirler.

Güneş Uyumlu Yörünge (Sun-Synchronous Orbit): Elektro-optik uyduların çoğu, belirli bölgelerin üzerinden günün hep aynı yerel saatinde geçecek şekilde güneşle uyumlu bir yörüngeye oturtulmuştur. Böylece bölgeye ait birden fazla görüntüdeki güneş açısı ve gölge durumunun ayn 1 olması sağlanmaktadır. Birçok uydu yörüngesi, güneş yükseklik açısının düşük olduğu ve gölgelerin arazinin tanınmasını kolaylaştırdığı sabah ile öğle saatleri arasında ekvatoru geçecek şekilde programlanmıştır.

Tarama Genişliği (Swath Width): Uydu algılayıcıları da hava kameraları gibi görüş açısına sahiptirler. Tarama genişliği kavramı görüş açısının yeryüzündeki enlemesine uzunluğunu ifade etmektedir. Yüksek çözünürlüğe sahip görüntülerin tarama genişliği genelde daha küçüktür.

Stereo Görüntüleme: Ayarlanabilir görüş geometrisine sahip uydular uçaklarda bulunan mekanizmadaki gibi bindirmeli görüntü çiftleri elde etmek suretiyle stereo görüntü kaydetme yeteneğine sahiptirler. 
Tekrarlama Süresi (Revisit Cyle): Bir uydu, daha önce belirlenmiş yörüngesinde hareket ederken belirli bir süre sonra yeryüzündeki aynı nokta üzerinden tekrar geçer. Aynı nokta üzerinden iki geçiş arasındaki zaman (gün olarak) "tekrarlama süresi" olarak adlandırılır. Ayarlanabilir görüntü açısına sahip alg1layıcılar (sensörler), bağlı olduğu uydunun tekrarlama süresinden daha hızlı görüntüleyebilme olanağına sahiptirler. $\mathrm{Bu}$ yetenek ile hızlı değişen ve siklıkla görüntülenmesi gereken sel, yangın gibi doğal afetlerde oldukça önemli ve gereklidir.

Görüş Geometrisi (Viewing Geometry): Elektro-optik ve SAR algılayıcıları sabit veya ayarlanabilir görüş geometrisine sahiptirler. Eğer algılayıcı sabit görüş açısına sahipse ya da belirli bir görüntüleme açısında (off-nadir angle) çalışıyorsa, algılayıcı direkt olarak aşağıya bakar ve bunun sonucunda uydunun iz düşümündeki (ground track) bölgeyi görüntüleyebilir. Ayarlanabilir algılayıcı ile bir kenardan diğerine veya ileri geri, izdüşümünün üzerinde veya dışarısında görüntüleme yapılabilir. Bundan dolay1 ayarlanabilir görüş geometrisi oldukça önemlidir. Çünkü uydunun tekrar aynı alanı görüntüleme ve stereo görüntüleme yapabilme özelliğini etkilemektedir (URL 4).

Alçalan ve Yükselen Yörüngeler (Descending and Ascending Orbits): Elektro-optik sistemler gibi pasif algılayıc1 taşıyan uyduların yörüngeleri yeryüzünün güneş alan tarafında alçalıp, karanlık tarafında yükselecek şekilde programlanmıştır. Buna karşın gün 1şı̆̆ına gereksinim duymayan SAR (Synthetic Aperture Radar - Yapay Açıklıklı Radar) algılayıcıs1 yörüngenin her bölümünde görüntü alabilmektedir. Şekil 2.1' de bir elips ile uydu yörüngesi ve onun temsilinin anlatımı görülmektedir. Şekilde;

- XYZ, jeosentrik çerçeve referans sistemini,

- $\Omega$, yükselen düğüm noktasının $(\mathrm{N})$ boylamın1,

- $\quad(\omega+v)$ uydu argümanını
- $\rho$, dünya merkezinden (O) uyduya olan uzaklı̆̆ını göstermektedir(Yılmaz, 2005).

Kutupsal Yörünge (Polar Orbit): Bütün sivil amaçlı uzaktan algılama uyduları kutupların yakınından geçen yörüngede kuzeydoğu-güneybatı yönünde hareket etmektedirler. Uydular, önceden belirlenmiş yörüngede sabit hiz ve yükseklilerde seyrederler. $\mathrm{Bu}$ nedenle uyduyu yerden kontrol eden birim tarafindan, istedikleri zamanda hız değişiklileri yapılması veya yörüngenin başka bir bölgeye kaydırılması mümkün değildir.

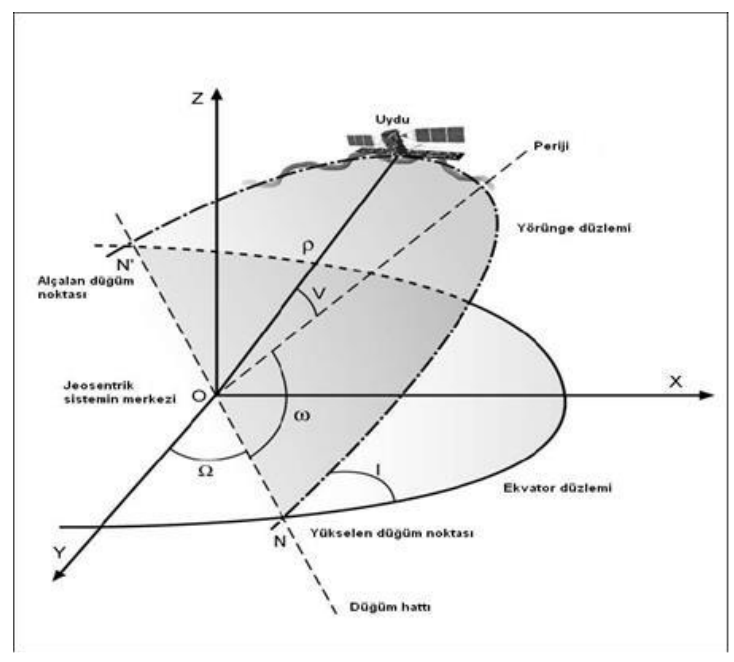

Şekil 1. Bir elips ile uydu yörüngesi ve onun temsilinin anlatımı (Yılmaz, 2005).

\section{Mekansal Çözünürlük (Spatial}

Resolution): Sensörün, en küçük hedefi ayırt etme kabiliyetinin ölçüsünü veya her bir pikselin temsil ettiği yeryüzündeki bir sahayı ifade eden terimdir. Görüntü seçimi yaparken dikkat edilmesi gereken en önemli özelliktir. Haritalanması planlanan alanın boyutları saptanabilmeli, tanımlanabilme ve doğru bir şekilde koordinatlandırılabilmesi için yeterli çözünürlüklü görüntü seçilmelidir.

Tayfsal Çözünürlük (Spektral Resolution): Elektromanyetik tayf üzerine kaydedilen verinin bant aralığına veya mesafesine karşılık gelir. Banda kaydedilen enerjinin dalga uzunluklarının arası geniş ise tayfsal çözünürlük düşük, dar ise tayfsal çözünürlük yüksektir demektir. 


\section{Zamansal Çözünürlük (Temporal} Resolution): Görüntüler arasındaki algılama aralığına karşılık gelir.

Radyometrik Çözünürlük (Radiometric Resolution): $\quad$ Elektromanyetik enerji miktarında sahip olunan hassasiyet radyometrik çözünürlüğü göstermektedir. Yani bir görüntüleme sisteminin çözünürlügü, enerji farklılıklarını ayırt edebilme yeteneğini gösterir. Sensörün parlaklık farklılıklarına olan hassasiyetini belirtmektedir. $2^{\mathrm{n}}$ ile ifade edilir (n: bit sayıs1).

GSD (Ground Sampling Distance) - Yer Örnekleme Aralığı: Kısaca bir pikselin arazideki karşılığıdır.

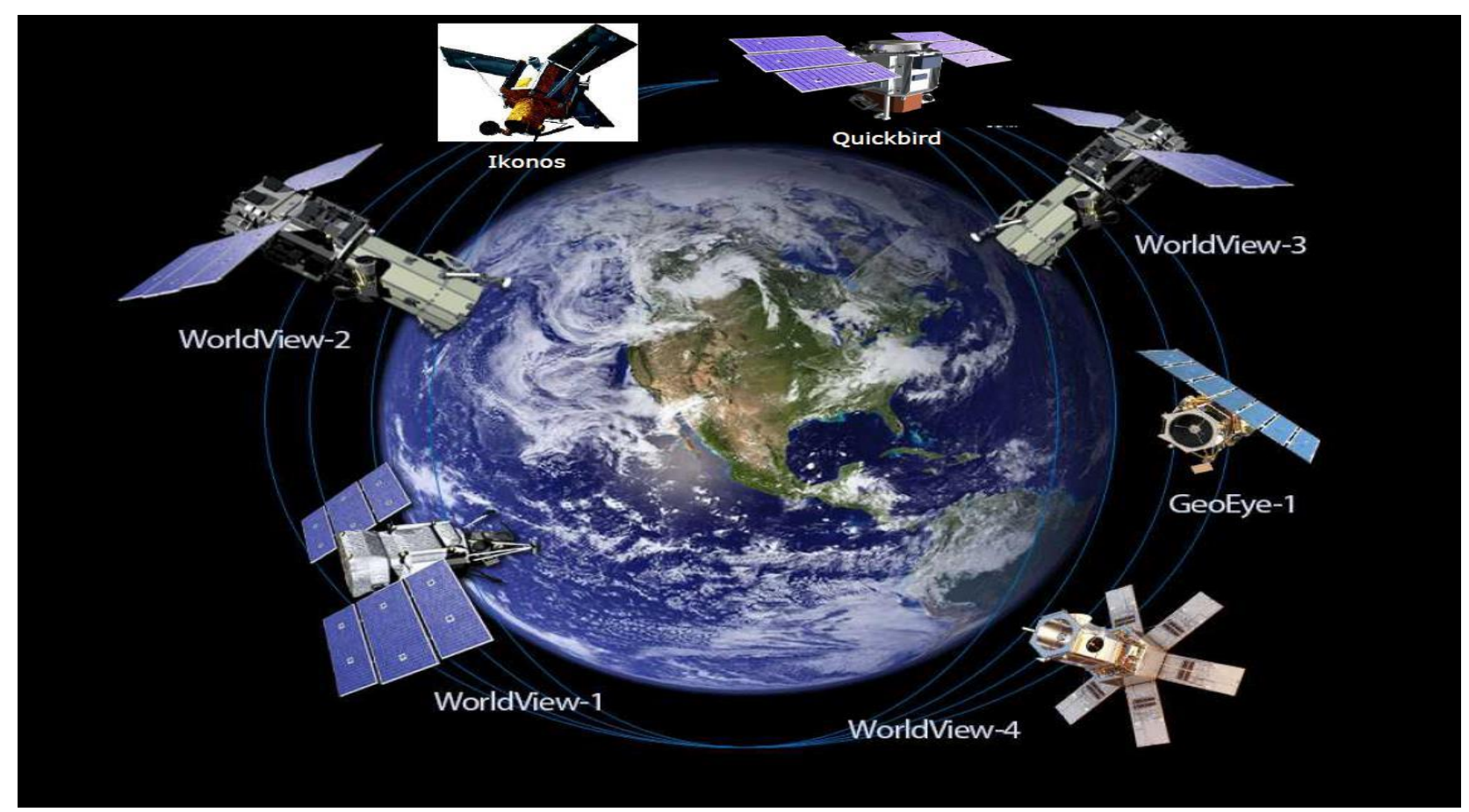

Şekil 2. Metre-altı çözünürlüğe sahip uydular (URL 5)

\section{Ikonos}

Ikonos uydusunun tasarım ve teknik özellikleri Tablo 1' de anlatılmıştır.

Ikonos uydusuna ait görüntü örneği Şekil 3' de gösterilmiştir.

\section{Quickbird}

Quickbird uydusunun tasarım ve teknik

özellikleri Tablo 2' de anlatılmıştır.

Quickbird uydusuna ait görüntü örneği Şekil 4' de gösterilmiştir.

\section{GeoEye-1}

GeoEye-1 uydusunun tasarım ve teknik özellikleri Tablo 3' de anlatılmıştır.
GeoEye-1 uydusuna ait görüntü örneği Şekil 5' de gösterilmiştir.

\section{Worldview-1}

Worldview-1 uydusunun tasarım ve teknik özellikleri Tablo 4' de anlatılmıştır.

Worldview-1 uydusuna ait görüntü örneği Şekil 6' da gösterilmiştir.

\section{Worldview-2}

Worldview-2 uydusunun tasarım ve teknik özellikleri Tablo 5' de anlatılmıştır.

Worldview-2 uydusuna ait görüntü örneği Şekil 7' de gösterilmiştir.

\section{Worldview-3}

Worldview-3 uydusunun tasarım ve teknik özellikleri Tablo 6' da anlatılmıştır. 
Worldview-3 uydusuna ait görüntü örneği Şekil 8' de gösterilmiştir.

\section{Worldview-4}

Worldview-4 uydusunun tasarım ve teknik özellikleri Tablo 7' de anlatılmıştır.

Worldview-4 uydusuna ait görüntü örneği Şekil 9' de gösterilmiştir.

\section{Uyduların Önemli Özelliklerinin Karşılaş̧ırılması}

Araştırılan uyduların yükseklik, gsd (pan ve $\mathrm{ms}$ ), tarama genişliği, toplama kapasitesi, ortalama tekrarlama süresi, tayfsal bantlar ve doğruluk gibi önemli özelliklerinin karşılaştırılması Tablo 8' de gösterilmiştir.

\section{SONUÇLAR ve ÖNERİLER}

\section{Sonuçlar}

Sunumda metre-altı çözünürlüğe sahip yüksek ve çok yüksek çözünürlüklü uydu görüntüleri elde etme imkanı sağlayan yedi adet uydu (IKONOS, QUICKBIRD, GEOEYE-1, WORLDVIEW-1, WORLDVIEW-2, WORLDVIEW-3 ve WORLDVIEW-4) dünya literatüründe var olan veriler yardımıyla araştırılıp incelenmiştir. $\mathrm{Bu}$ uydular, donanımları, faydaları, tasarım ve teknik özellikler kapsamında ele alınarak seminer çalışmasında anlatılmıştır. Uydu görüntülerinin seçiminde istenilen ürünün ihtiyaç, hassasiyet, doğruluk ve kullanılabilirlik alanları kapsamında araştırılıp yapılmasına dikkat edilmelidir. En güncel ve en yüksek çözünürlüğe sahip olan Worldview4 uydusunun özellikleri ise Worldview-3 uydusu ile oldukça benzerlik göstermektedir.

\section{Öneriler}

Ülkemizin uzaysal araştırmalar ile ilgili ajansı olan TUSAŞ' in üzerine bu konuyla ilgili büyük görev düşmektedir. Gelişmiş ülkelerde olduğu gibi, bu uzay ajansı ile Türkiye'nin uzaydan daha fazla istifade etmesi sağlanacaktır. Ülke olarak kendi uydularımızı firlatacağımız bir uydu firlatma merkezinin de kurulmasına yönelik AR-GE çalışmaları yapılmalı ve buna yönelik faaliyetler başlatılmalıdır.
Küresel ölçekte var olan uzay çalışmaları rekabeti içerisinde Türkiye olarak var olmamız önem arz etmektedir. Bu sayede mühendislik çalışmaları, özellikle de Harita Mühendisliği fotogrametri ve uzaktan algılama ana bilim dallarında harita üretim faaliyetlerinde pratiklik kazandırılmalıdır.

\section{KAYNAKLAR}

Atak, V,O, 2007, Yüksek Çözünürlüklü Uydu Görüntülerinin Geometrik Doğruluk ve Detay Değerlendirme Yönünden İncelenmesi, Doktora Tezi, İstanbul Teknik Üniversitesi Fen Bilimleri Enstitüsü, İstanbul.

Bilgi, S., 2006, Fotogrametri ve Uzaktan Algilamada Veri Elde Etme Yöntemlerinin Gelişimi ve Kısa Tarihçeleri, Jeodezi, Jeoinformasyon ve Arazi Yöneyimi Dergisi 2007/1, Say1 96.

Gürbüz, H., 2006, Genel Fotogrametri 1, Birlik Matbaacilık, Ankara, 11, 213.

Li, R., Zhou, G., Yang, S., Tuell, G., Schmidt, N. J., Fowler, C., 2000, A Study of the Potential Attainable Geometric Accuracy of Ikonos Satellite Imagery, IXX. Uluslararas1 Fotogrametri ve Uzaktan Algılama Birliği (ISPRS) Kongresi, Komisyon IV, Çalışma Grubu IV/6, 16-23 Temmuz 2000, AmsterdamHollanda.

Önder, M., 1998, Uzaktan Algılama Ders Notlar1, Hacettepe Üniversitesi Mühendislik Fakültesi, Ankara.

Önder, M., 1998, Uydu Görüntülerinden - Ulusal Coğrafi Bilgi Sistemine Temel Oluşturacak Nitelikte - Topoğrafik Harita Üretimine Veya Güncelleştirmesine Yönelik Analiz ve Öneriler, Doktora Tezi, Yıldız Teknik Üniversitesi Fen Bilimleri Enstitüsü, İstanbul.

Önder, M., 1999, Uzaktan Algılama Ders Kitabı, Kara Harp Okulu Basımevi, Ankara.

Önder, M., 2002, Geçmişten Günümüze Resimlerle Türk Haritacılık Tarihi, Harita Genel Komutanlığı Matbaası, Ankara.

Özbalmumcu, M., 2003, Uydu Görüntülerinin Temin Edilmesi ve Kullanılmasına Yönelik Temel Esaslar, Silahlı Kuvvetler Dergisi, Genel Kurmay Basımevi, Ankara, 375, 29-50.

Yılmaz, A., 2002, Farklı Kaynaklardan Üretilen Sayısal Yükseklik Modellerinin Doğruluk Araştırması, Yüksek Lisans Tezi, Yıldız 
Teknik Üniversitesi Fen Bilimleri Enstitüsü, İstanbul.

(URL 1)

https://www.isprs.org/documents/default.a spx [Ziyaret Tarihi: 10 Ocak 2017].

(URL 2) https: //www.asprs.org/about [Ziyaret

Tarihi: 12 Ocak 2017].

(URL 3) https: //www.uzay.tubitak.gov.tr/projeler [Ziyaret Tarihi: 12 Ocak 2017].

(URL 4)

https://www.nik.com.tr/content/sistem_uy d u_ gö r ün tüler i_r ehb er_kitap çı ğ $1 . a$ sp

(URL 5)

[Ziyaret Tarihi: 12 Ocak 2017].

https://www.euspaceimaging.com/satellite s [Ziyaret Tarihi: 27 Aralık 2017].

(URL 6)

https://www.digitalglobe.com/resources/sa tellite-information [Ziyaret Tarihi: 15 Aralık 2016].

(URL 7)

https://www.digitalglobe.com/resources/sa tellite-information/IKONOS.pdf [Ziyaret Tarihi: 15 Aralık 2016].

(URL 8)

https://www.digitalglobe.com/resources/sa tellite-information/QUICKBIRD.pdf [Ziyaret Tarihi: 15 Aralık 2016]

(URL 9)

https://www.digitalglobe.com/resources/sa tellite-information/GEOEYE-1.pdf [Ziyaret Tarihi: 15 Aralık 2016]

(URL 10)

https://www.digitalglobe.com/resources/sa tellite-information/WORLDVIEW-1.pdf [Ziyaret Tarihi: 15 Aralık 2016].

(URL 11)

https://www.digitalglobe.com/resources/sa tellite-information/WORLDVIEW-2.pdf
(URL 12)

[Ziyaret Tarihi: 15 Aralık 2016].

https://www.digitalglobe.com/resources/sa tellite-information/WORLDVIEW-3.pdf [Ziyaret Tarihi: 15 Aralık 2016].

(URL 13)

https://www.digitalglobe.com/resources/sa tellite-information/WORLDVIEW-4.pdf

[Ziyaret Tarihi: 15 Aralık 2016].

(URL 14)

https://www.satimagingcorp.com/gallery/i (URL 15)

konos [Ziyaret Tarihi: 18 Ocak 2017].

(URL 16)

https://www.satimagingcorp.com/gallery/q uickbird [Ziyaret Tarihi: 18 Ocak 2017].

https://www.satimagingcorp.com/gallery/g eoeye-1 [Ziyaret Tarihi: 18 Ocak 2017].

(URL 17)

https://www.satimagingcorp.com/gallery/ worldview-1 [Ziyaret Tarihi: 18 Ocak 2017].

(URL 18)

https://www.satimagingcorp.com/gallery/ worldview-2 [Ziyaret Tarihi: 18 Ocak 2017]

(URL19)

https://www.satimagingcorp.com/gallery/ worldview-3 [Ziyaret Tarihi: 18 Ocak 2017].

URL 20)

https://www.satimagingcorp.com/gallery/ worldview-4 [Ziyaret Tarihi: 18 Ocak 2017].

URL 21)

https://www.digitalglobe.com/products/ste reo-imagery [Ziyaret Tarihi: 20 Ocak 2017]. 
Uysal, E. / Uzay Fotogrametrisi

\begin{tabular}{|c|c|}
\hline \multicolumn{2}{|c|}{ TASARIM VE TEKNIK ÖZELLIKLERİ } \\
\hline Firlatılma Bilgileri & $\begin{array}{l}\text { Tarih: } 24 \text { Eylül } 1999 \\
\text { Yörünge Yerleştirme Aracı: Athena II } \\
\text { Fırlatma Yeri: Vandenberg Hava Üssü, California }\end{array}$ \\
\hline Yörünge & $\begin{array}{l}\text { Aç1: } 98.1^{\circ} \text { Yükseklik: } 681 \mathrm{~km} \\
\text { Tür: Güneş Uyumlu, alçalan düğüm noktasından, 10:30 } \\
\text { Dönüş Süresi: } 200 \mathrm{~km} / 11 \text { saniye }\end{array}$ \\
\hline Görev Süresi & 12+ yıl (31.03.2015'de görev süresi tamamlanmıştır) \\
\hline Uzay Aracı Boyutu & Boyut:1.83x1.57 m (altıgen yapılandırma) Ağırlık:725 kg \\
\hline \multirow[b]{2}{*}{ Mekansal ve Tayfsal Çözünürlük } & $\begin{array}{l}\text { Pankromatik: } 0.82 \mathrm{~m} \text { GSD } \\
\text { Çok bantl1: } 3.2 \mathrm{~m}\end{array}$ \\
\hline & $\begin{array}{l}\text { Pankromatik: } 450-900 \mathrm{~nm} \\
\text { Çok bantlı: Mavi: } 445-516 \mathrm{~nm} \text {, Yeşil: } 506 \text { - } 595 \mathrm{~nm}, \text { Kırmızı: } 632-698 \mathrm{~nm} \\
\text { Yakın Kızılötesi: } 757-853 \mathrm{~nm}\end{array}$ \\
\hline Konumsal (Metrik) Doğruluk & $\begin{array}{l}15 \text { m CE90 (Şartname) } \\
9 \text { m CE90 (Ölçülen) }\end{array}$ \\
\hline Tarama Genişliği & $11.3 \mathrm{~km}$ \\
\hline Dinamik Aralık & Piksel başına 11-bit \\
\hline D1ş Nadir Görüntüleme & $60^{\circ}$ ye kadar \\
\hline $\begin{array}{l}\text { Tekrarlama Süresi } \\
\left(40^{\circ} \text { Enleminde }\right)\end{array}$ & Yaklaşık 3 gün \\
\hline Toplama Kapasitesi & Günlük 240000 km² $^{2}$ pankromatik + çok bantlı) \\
\hline Geniş Alan Toplama & $112 \mathrm{~km} \times 51 \mathrm{~km}$ \\
\hline Stereo Alan Toplama & $120 \mathrm{~km} \times 11 \mathrm{~km}$ \\
\hline Uygulama Alanları & $\begin{array}{l}\text { Doğal kaynakların ve afetlerin hem kentsel hem kırsal olmak üzere } \\
\text { haritalanması, vergi haritalama, savunma ve istihbarat, tarım ve ormancılık } \\
\text { analizi, madencilik, mühendislik, inşaat ve değişiklik algılama, kıyı izleme, }\end{array}$ \\
\hline Elde Edilen Ürünler & $\begin{array}{l}\text { DEM, DTM, DSM } \\
\text { Temel(Ham)Görüntü, Orto-Hazır Görüntü } \\
\text { Ortorektifiye edilmiş Görüntü } \\
\text { Geo, GeoStereo, GeoTIFF }\end{array}$ \\
\hline
\end{tabular}

Tablo 1. Ikonos uydusunun tasarım ve teknik özellikleri

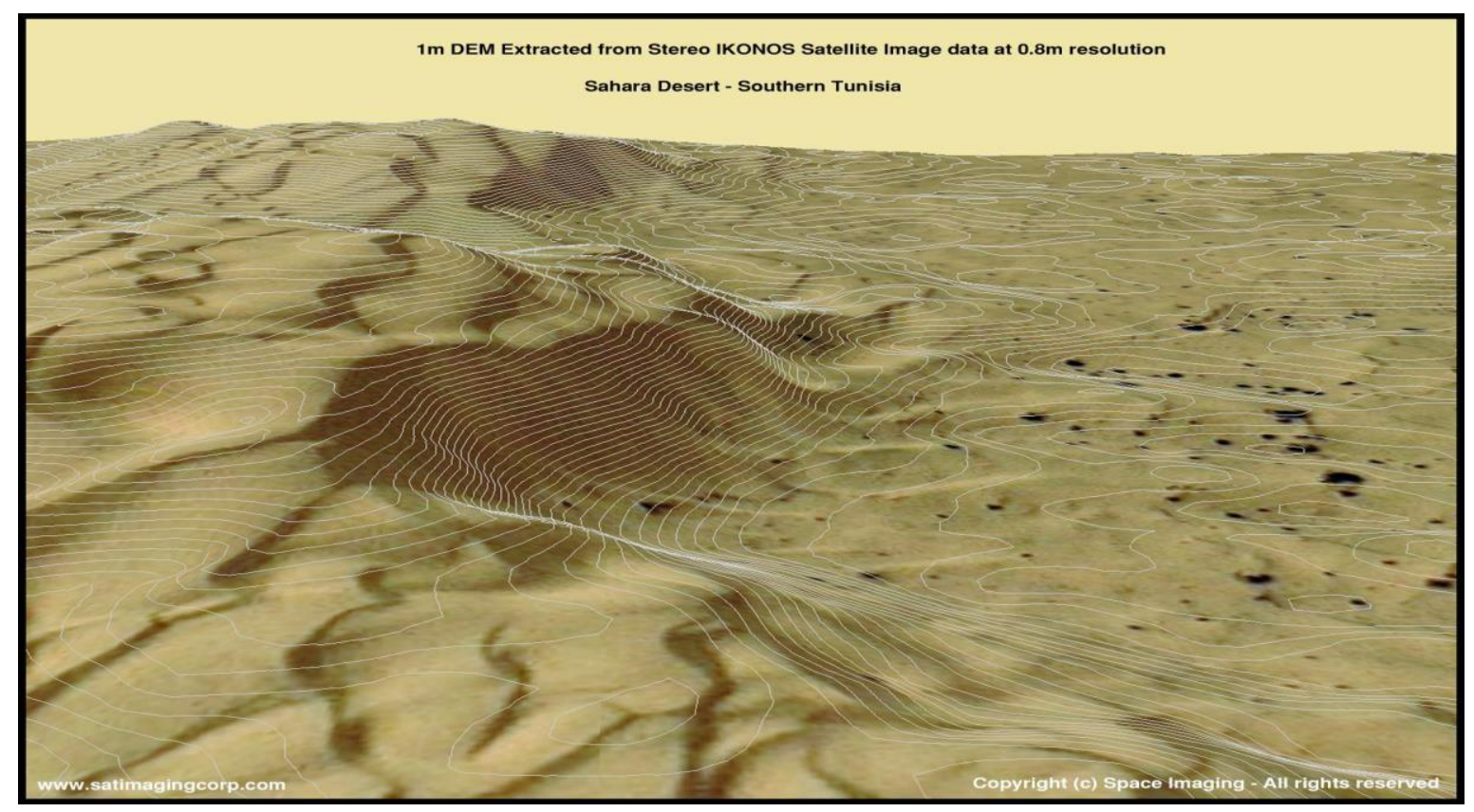

Şekil 3. Ikonos uydu görüntüsü örneği (URL 14) 


\begin{tabular}{|c|c|c|}
\hline \multicolumn{3}{|c|}{ TASARIM VE TEKNIKK ÖZELLIKLERİ } \\
\hline Firlatılma Bilgileri & \multicolumn{2}{|c|}{$\begin{array}{l}\text { Tarih: } 18 \text { Ekim } 2001 \\
\text { Yörünge Yerleştirme Aracı: Delta II } \\
\text { Firlatma Yeri: Vandenberg Hava Üssü, California }\end{array}$} \\
\hline \multirow{3}{*}{ Yörünge } & \begin{tabular}{l|l}
$450 \mathrm{~km}$ yükseklikte & \\
\end{tabular} & $300 \mathrm{~km}$ yükseklikte \\
\hline & Aç1: $97.2^{\circ}$ & Aç1: $97.2^{\circ}$ \\
\hline & $\begin{array}{l}\text { Tür: Güneş uyumlu, alçalan düğüm } \\
\text { noktasindan 10:00, Periyot: } 93.6 \mathrm{dk}\end{array}$ & $\begin{array}{l}\text { Tür: Güneş uyumlu, alçalan düğüm } \\
\text { noktasından 10:00, Periyot: } 90.4 \mathrm{dk}\end{array}$ \\
\hline Görev Süresi & \multicolumn{2}{|c|}{14 y1l (27.01.2015'de görev süresi tamamlanmıștır) } \\
\hline Uzay Aracı Boyutu & \multicolumn{2}{|c|}{ Uzunluk: $3.04 \mathrm{~m}$, Ağırlık: $1089,6 \mathrm{~kg}$} \\
\hline \multirow{3}{*}{$\begin{array}{l}\text { Mekansal ve Tayfsal } \\
\text { Çözünürlük }\end{array}$} & $450 \mathrm{~km}$ yükseklikte & $300 \mathrm{~km}$ yükseklikte \\
\hline & $\begin{array}{l}\text { Pankromatik: } 0.61 \mathrm{~m} \mathrm{GSD} \\
\text { Çok bantl1: } 2.44 \mathrm{~m} \text { GSD }\end{array}$ & $\begin{array}{l}\text { Pankromatik: } 0.41 \mathrm{~m} \text { GSD } \\
\text { Çok bantlı: } 1.63 \mathrm{~m} \text { GSD }\end{array}$ \\
\hline & \multicolumn{2}{|c|}{$\begin{array}{l}\text { Pankromatik: } 405-1053 \mathrm{~nm} \\
\text { Mavi:430 - } 545 \mathrm{~nm} \text {, Yeşil: } 466 \text { - } 620 \mathrm{~nm}, \text { Kırmızı: } 590 \text { - } 710 \mathrm{~nm} \\
\text { Yakın Kızı̈̈tesi: } 715 \text { - } 918 \mathrm{~nm}\end{array}$} \\
\hline $\begin{array}{l}\text { Konumsal (Metrik) } \\
\text { Doğruluk }\end{array}$ & \multicolumn{2}{|c|}{23 m CE90 (yatay), 17 m LE90 (düşey) [Yer Kontrol Noktası]] } \\
\hline Tarama Genişliği & $16.8 \mathrm{~km}$ & $11.2 \mathrm{~km}$ \\
\hline Dinamik Aralık & \multicolumn{2}{|c|}{ Piksel başına 11-bit } \\
\hline Konum Belirleme ve Kontrol & \multicolumn{2}{|c|}{$\begin{array}{l}\text { Tür: } 3 \text { eksenli stabilize } \\
\text { Algılayıcılar: Y1ldız izleyici/ IRU/ Reaksiyon çark1/ GPS }\end{array}$} \\
\hline $\begin{array}{l}\text { Tekrarlama Süresi } \\
\left(40^{\circ} \text { Enleminde }\right)\end{array}$ & $\begin{array}{l}1 \mathrm{~m} \text { veya daha az GSD } 2.4 \text { gün } \\
20^{\circ} \text { diş nadir veya daha az açıda } 5.9 \\
\text { gün }\end{array}$ & $\begin{array}{l}1 \mathrm{~m} \text { veya daha az GSD } 2.1 \text { gün } \\
20^{\circ} \text { diş nadir veya daha az açıda } 8.7 \text { gün }\end{array}$ \\
\hline Toplama Kapasitesi & Günlük $200000 \mathrm{~km}^{2}$ & Günlük $100000 \mathrm{~km}^{2}$ \\
\hline $\begin{array}{l}\text { Yeniden Hedefleme } \\
\text { Kabiliyeti }\end{array}$ & $200 \mathrm{~km} / 38$ saniye & $200 \mathrm{~km} / 44$ saniye \\
\hline Uydu Üzerinde Depolama & \multicolumn{2}{|c|}{$128 \mathrm{~GB}$} \\
\hline İletişim & \multicolumn{2}{|c|}{$\begin{array}{l}\text { Veri Taşıma Kapasitesi: 320Mbps X-bant } \\
\text { Kayit Tutma: X-bant 4, } 16 \text { ve } 256 \mathrm{kbps}, 2 \text { Kbps S-bant }\end{array}$} \\
\hline Uygulama Alanları & \multicolumn{2}{|c|}{$\begin{array}{l}\text { Arazi yönetimi, tarımsal ve orman değişikliklerinin izlenip analiz edilmesinde, } \\
\text { petrol ve gaz araştırmalarında ve üretiminde, mühendislik ve inşaat ( } 3 \mathrm{~d} \text { şehir ve } \\
\text { kent modelleme, kentsel gelişim ve kalkınma, kadastro ve arazi kayıtları vb.), } \\
\text { tarihi yerlerin görüntülenmesi, savunma ve istihbarat }\end{array}$} \\
\hline Elde Edilen Ürünler & \multicolumn{2}{|c|}{$\begin{array}{l}\text { DEM, DTM, DSM } \\
\text { Temel(Ham)Görüntü, Orto-Hazır Görüntü } \\
\text { Ortorektifiye edilmiş Görüntü } \\
\text { Geo, GeoStereo, GeoTIFF }\end{array}$} \\
\hline
\end{tabular}

Tablo 2. Quickbird uydusunun tasarım ve teknik özellikleri (URL 8)

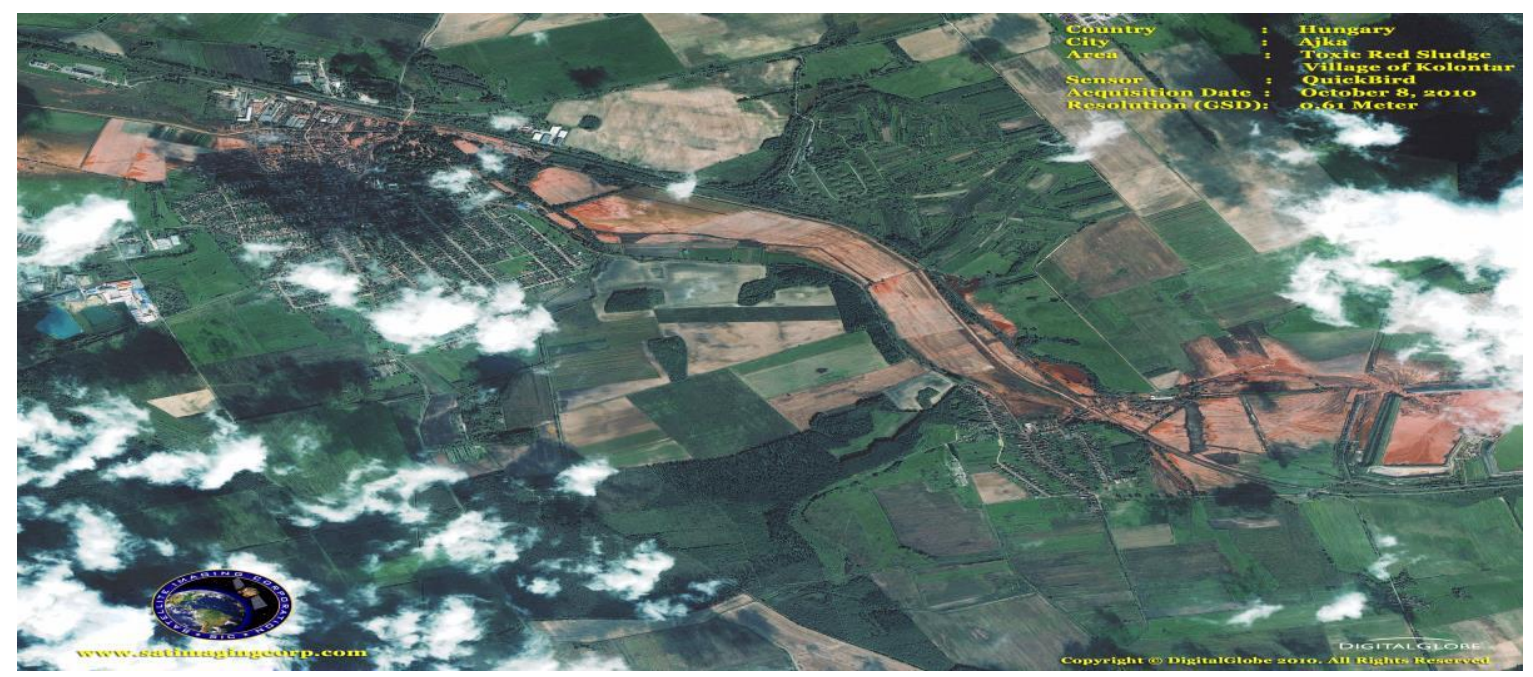

Şekil 4. Quickbird uydu görüntüsü örneği (doğal felaketler) (URL 15) 


\begin{tabular}{|c|c|}
\hline \multicolumn{2}{|r|}{ TASARIM VE TEKNIK ÖZELLIKLLRİ } \\
\hline Firlatılma Bilgileri & $\begin{array}{l}\text { Tarih: } 6 \text { Eylül } 2008 \\
\text { Yörünge Yerlestirme Aracı: Delta II } \\
\text { Furlatma Yeri: Vandenberg Hava Üssü, California }\end{array}$ \\
\hline Yörünge & $\begin{array}{l}\text { Aç1: } 98^{\circ}, \text { Yükseklik: } 681 \mathrm{~km} \\
\text { Tür: Güneş uyumlu, alçalan düğüm noktasından 10:30, } \\
\text { Periyot: } 98 \text { dakika }\end{array}$ \\
\hline Görev Süresi & $10+$ y1l \\
\hline Uzay Aracı Boyutu & Uzunluk: 4.34 m, Ağırlık: $1898 \mathrm{~kg}$ \\
\hline \multirow{2}{*}{$\begin{array}{l}\text { Mekansal ve Tayfsal } \\
\text { Çözünürlük }\end{array}$} & $\begin{array}{l}\text { Pankromatik: } 0.41 \mathrm{~m} \mathrm{GSD} \\
\text { Cok bantl1: } 1.65 \mathrm{~m} \text { GSD }\end{array}$ \\
\hline & $\begin{array}{l}\text { Pankromatik: } 450 \text { - } 800 \mathrm{~nm} \\
\text { Çok bantl1: Mavi: } 450 \text { - } 510 \mathrm{~nm} \text {, Yeşil: } 510 \text { - } 580 \mathrm{~nm} \text {, Kırmızı: } 655 \text { - } 690 \mathrm{~nm} \\
\text { Yakın Kızılötesi: } 780 \text { - } 920 \mathrm{~nm}\end{array}$ \\
\hline $\begin{array}{l}\text { Konumsal (Metrik) } \\
\text { Doğruluk }\end{array}$ & $\begin{array}{l}5 \mathrm{~m} \text { CE90 (Şartname ) } \\
3 \mathrm{~m} \text { CE90 (Ölçülen) }\end{array}$ \\
\hline Tarama Genişliği & $15.3 \mathrm{~km}$ \\
\hline Dinamik Aralık & Piksel başına 11-bit \\
\hline $\begin{array}{l}\text { Konum Belirleme ve } \\
\text { Kontrol }\end{array}$ & $\begin{array}{l}\text { Tür: } 3 \text { eksenli stabilize } \\
\text { Algilayıcılar: Yıldız izleyici /IRU /Reaksiyon çark1 /GPS }\end{array}$ \\
\hline $\begin{array}{l}\text { Tekrarlama Süresi } \\
\left(40^{\circ} \text { Enleminde }\right)\end{array}$ & $30^{\circ}$ lik dış nadir açısında 2.6 gün \\
\hline Toplama Kapasitesi & Günlük $350000 \mathrm{~km}^{2}$ \\
\hline $\begin{array}{l}\text { Yeniden Hedefleme } \\
\text { Kabiliyeti }\end{array}$ & $200 \mathrm{~km} / 20$ saniye \\
\hline Uydu Üzerinde Depolama & $1 \mathrm{~TB}$ \\
\hline İletişim & $\begin{array}{l}\text { Veri Taşıma Kapasitesi: X-bant 740/150 Mbps, AES/ DES türünde şifreleme } \\
\text { Kayıt Tutma: X-bant } 64 \mathrm{kbps} \text {, AES türünde şifreleme }\end{array}$ \\
\hline Uygulama Alanları & $\begin{array}{l}\text { Tarım ve ziraat, arkeoloji, kadastral ve arazi uygulamaları, güncel ve dünya olayları, } \\
\text { Askeri ve istihbarat, mühendislik ve inşaat, çevresel uygulamalar, doğal afetler, oyun } \\
\text { tasarım, madencilik }\end{array}$ \\
\hline Elde Edilen Ürünler & $\begin{array}{l}\text { DEM, DTM, DSM } \\
\text { Temel(Ham)Görüntü, Orto-Hazır Görüntü } \\
\text { Ortorektifiye edilmiş Görüntü } \\
\text { Geo, GeoStereo, GeoTIFF }\end{array}$ \\
\hline
\end{tabular}

Tablo 3. Geo-Eye1 uydusunun tasarım ve teknik özellikleri (URL 9)

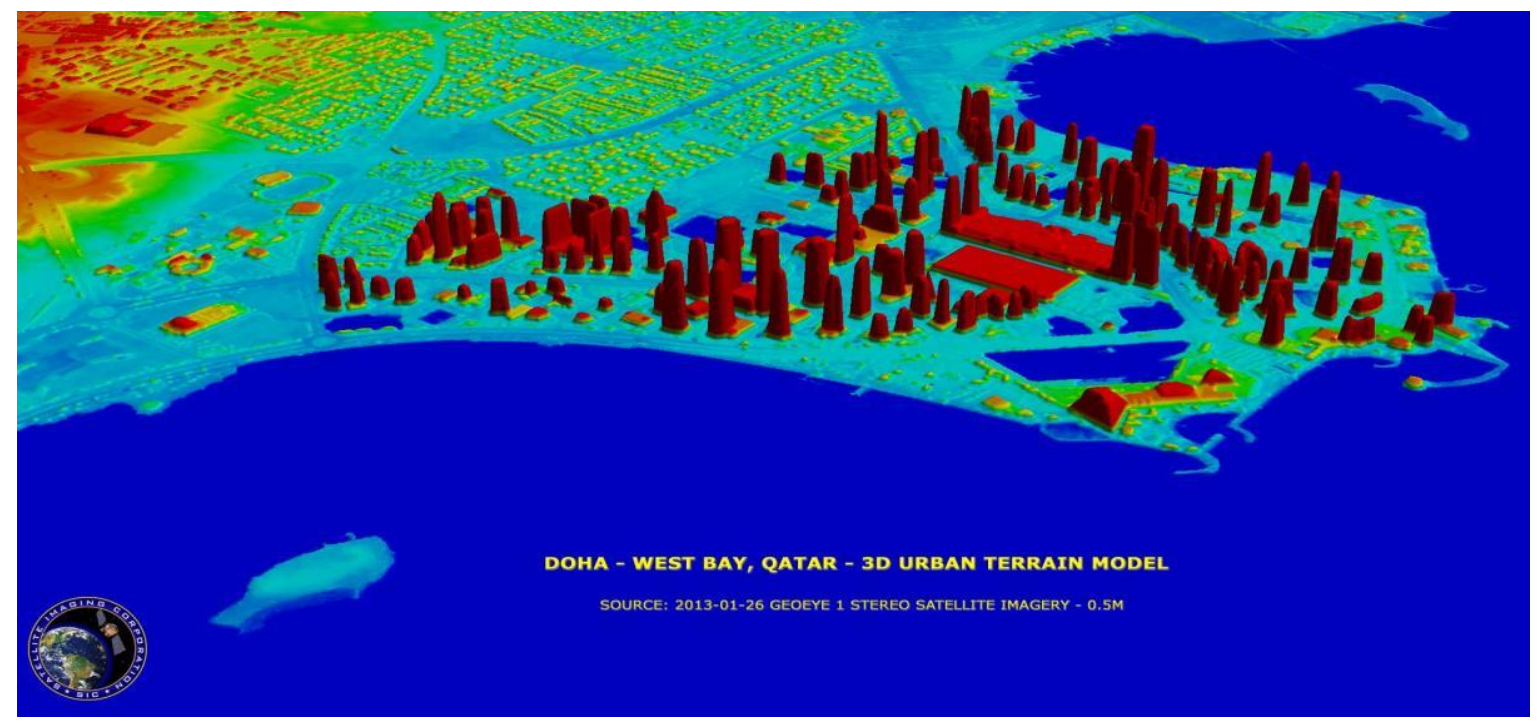

Şekil 5. GeoEye-1 uydu görüntüsü örneği (yüzey modeli) (URL 16) 


\begin{tabular}{|c|c|}
\hline \multicolumn{2}{|r|}{ TASARIM VE TEKNIK ÖZELLIKLERİ } \\
\hline Firlatılma Bilgileri & $\begin{array}{l}\text { Tarih: } 18 \text { Eylül } 2007 \\
\text { Yörünge Yerleştirme Aracı: Delta } 7920 \text { ( } 9 \text { kayış) } \\
\text { Firlatma Yeri: Vandenberg Hava Üssü, California }\end{array}$ \\
\hline Yörünge & $\begin{array}{l}\text { Yükseklik: } 496 \mathrm{~km} \\
\text { Tür: Güneş uyumlu, alçalan düğüm noktasından 10:30, } \\
\text { Periyot: } 95 \text { dakika }\end{array}$ \\
\hline Görev Süresi & $10-12$ y1l \\
\hline Uzay Aracı Boyutu & $\begin{array}{l}\text { Boyut } 3.6 \times 2.5 \mathrm{~m} \text {, Ağırlık: } 2290 \mathrm{~kg}, 7.1 \mathrm{~m} \text { boyutlarında güneş paneli uzunluğu, } \\
3.2 \mathrm{~kW} \text { güneş enerjisi, } 100 \mathrm{Ahr} \text { batarya }\end{array}$ \\
\hline \multirow[t]{2}{*}{$\begin{array}{l}\text { Mekansal ve Tayfsal } \\
\text { Çözünürlük }\end{array}$} & $\begin{array}{l}\text { Pankromatik: } 0.50 \mathrm{~m} \text { GSD } \\
20^{\circ} \text { lik diş nadir açısında } 0.55 \mathrm{~m} \text { GSD }\end{array}$ \\
\hline & Pankromatik: $400-900 \mathrm{~nm}$ \\
\hline Konumsal (Metrik) Doğruluk & 4 m’ den küçük CE90 (Yer Kontrol Noktası) \\
\hline Tarama Genişliği & $17.7 \mathrm{~km}$ \\
\hline Dinamik Aralık & Piksel başına 11-bit \\
\hline Konum Belirleme ve Kontrol & $\begin{array}{l}\text { Tür: } 3 \text { eksenli stabilize } \\
\text { Aktüatör: CMG } \\
\text { Algılayıcılar: Yıldız izleyici/ Yarı iletken IRU /GPS }\end{array}$ \\
\hline Noktalama Doğruluğu ve Bilgi & $\begin{array}{l}\text { Doğruluk: Görüntü başlama ve bitişlerinde }<500 \mathrm{~m} \\
\text { Bilgi: Coğrafi konum doğruluğunu destekler. }\end{array}$ \\
\hline $\begin{array}{l}\text { Tekrarlama Süresi } \\
\left(40^{\circ} \text { Enleminde }\right)\end{array}$ & $\begin{array}{l}1 \text { m GSD' de ya da daha az çözünürlükte } 1.7 \text { gün } \\
20^{\circ} \text { lik diş nadir açısında } 5.4 \text { gün }\end{array}$ \\
\hline Toplama Kapasitesi & Günlük 1.3 milyon $\mathrm{km}^{2}$ \\
\hline $\begin{array}{l}\text { Tek Geçişte Sürekli } \\
\text { Toplanabilecek En Fazla Alan }\end{array}$ & $\begin{array}{l}\text { Mono: } 111 \text { x } 112 \mathrm{~km}(6 \mathrm{kolon}) \\
\text { Stereo: } 51 \text { x } 112 \mathrm{~km} \text { (3 çift) }\end{array}$ \\
\hline Yeniden Hedefleme Kabiliyeti & $200 \mathrm{~km} / 10$ saniye \\
\hline Uydu Üzerinde Depolama & 2199 GB' l1k yarı iletken disk \\
\hline İletişim & $\begin{array}{l}\text { Görüntü ve Yardımcı Veri: X-bant } 800 \text { Mbps, } \\
\text { Kayıt Tutma: X-bant 4, 16, } 32 \text { kbps gerçek zamanlı; } 524 \text { kbps depolanmış } \\
\text { Uzaktan Kumanda: } 2 \text { ya da } 64 \text { kbps S-bant }\end{array}$ \\
\hline Uygulama Alanları & $\begin{array}{l}\text { İletişim, Altyapı planlama haritaları ve ölçümü, mühendislik ve inşaat, koridor } \\
\text { haritalama, madencilik ve arama, petrol ve gaz, güncel ve dünya olayları }\end{array}$ \\
\hline Elde Edilen Ürünler & $\begin{array}{l}\text { DEM, DTM, DSM } \\
\text { Temel(Ham)Görüntü, Orto-Hazır Görüntü } \\
\text { Ortorektifiye edilmiş Görüntü } \\
\text { Geo, GeoStereo, GeoTIFF }\end{array}$ \\
\hline
\end{tabular}

Tablo 4. Worldview-1 uydusunun tasarım ve teknik özellikleri (URL 10)

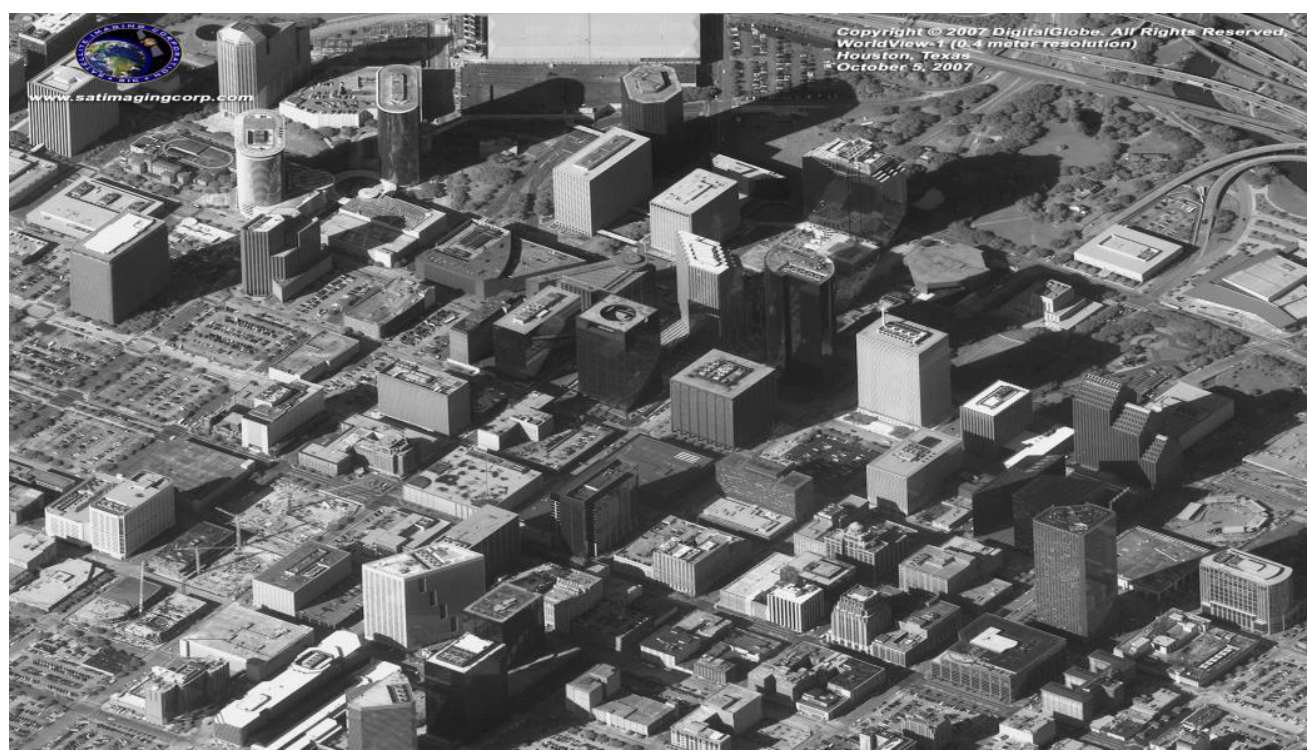

Şekil 6. Worldview-1 uydusunun ilk uydu görüntüsü (URL 17) 


\begin{tabular}{|c|c|}
\hline \multicolumn{2}{|r|}{ TASARIM VE TEKNIK ÖZELLIKLERİ } \\
\hline Firlatılma Bilgileri & $\begin{array}{l}\text { Tarih: } 8 \text { Ekim } 2009 \\
\text { Yörünge Yerleştirme Aracı: Delta } 7920 \text { ( } 9 \text { kayış) } \\
\text { Fırlatma Yeri: Vandenberg Hava Üssü, California }\end{array}$ \\
\hline Yörünge & $\begin{array}{l}\text { Yükseklik: } 770 \mathrm{~km} \\
\text { Tür: Güneş uyumlu, alçalan düğüm noktasından 10:30, } \\
\text { Periyot: } 100 \text { dakika }\end{array}$ \\
\hline Görev Süresi & $10-12$ y1l \\
\hline Uzay Aracı Boyutu & $\begin{array}{l}\text { Boyut: } 5.7 \text { x } 2.5 \mathrm{~m} \text {, Ağırlık: } 2615 \mathrm{~kg}, 7.1 \mathrm{~m} \text { boyutlarında güneş paneli uzunluğu, } \\
3.2 \mathrm{~kW} \text { güneş enerjisi, } 100 \text { Ahr batarya }\end{array}$ \\
\hline \multirow[b]{2}{*}{$\begin{array}{l}\text { Mekansal ve Tayfsal } \\
\text { Çözünürlük }\end{array}$} & $\begin{array}{l}\text { Pankromatik: } 0.46 \mathrm{~m}, 20^{\circ} \text { lik diş nadir açısında } 0.52 \mathrm{~m} \mathrm{GSD} \\
\text { Çok bantlı: } 1.85 \mathrm{~m}, 20^{\circ} \text { lik diş nadir açısında } 2.07 \mathrm{~m} \text { GSD }\end{array}$ \\
\hline & $\begin{array}{ll}\text { Pankromatik: } 400-900 \mathrm{~nm} & \\
\text { Kıy1: } 400-450 \mathrm{~nm} & \text { Kırmızı: } 630-690 \mathrm{~nm} \\
\text { Mavi: } 450-510 \mathrm{~nm} & \text { Kırmızı Kenar: } 705-745 \mathrm{~nm} \\
\text { Yeşil: } 510-580 \mathrm{~nm} & \text { Yakın Kızı̈ötesi 1: } 770-895 \mathrm{~nm} \\
\text { Sarı: } 585-625 \mathrm{~nm} & \text { Yakın Kızı̈ötesi 2: } 860-1040 \mathrm{~nm} \\
\end{array}$ \\
\hline Konumsal (Metrik) Doğruluk & 3.5 m’ den küçük CE90 (Yer Kontrol Noktasız) \\
\hline Tarama Genişliği & $16.4 \mathrm{~km}$ \\
\hline Dinamik Aralık & Piksel başına 11-bit \\
\hline Konum Belirleme ve Kontrol & $\begin{array}{l}\text { Tür: } 3 \text { eksenli stabilize } \\
\text { Aktüatör: CMG } \\
\text { Algılayıcılar: Yıldız izleyici/ Yarı iletken IRU /GPS }\end{array}$ \\
\hline Noktalama Doğruluğu ve Bilgi & $\begin{array}{l}\text { Doğruluk: Görüntü başlama ve bitişlerinde }<500 \mathrm{~m} \\
\text { Bilgi: Coğrafi konum doğruluğunu destekler. }\end{array}$ \\
\hline $\begin{array}{l}\text { Tekrarlama Süresi } \\
\left(40^{\circ} \text { Enleminde }\right)\end{array}$ & $\begin{array}{l}1 \text { m GSD' de ya da daha az çözünürlükte } 1.1 \text { gün } \\
20^{\circ} \text { lik diş nadir açısında } 3.7 \text { gün }\end{array}$ \\
\hline Toplama Kapasitesi & Günlük 1 milyon $\mathrm{km}^{2}$ \\
\hline $\begin{array}{c}\text { Tek Geçişte Sürekli } \\
\text { Toplanabilecek En Fazla Alan }\end{array}$ & $\begin{array}{l}\text { Mono: } 138 \times 112 \mathrm{~km}(8 \mathrm{kolon}) \\
\text { Stereo: } 63 \text { x } 112 \mathrm{~km} \text { (4 çift) }\end{array}$ \\
\hline Yeniden Hedefleme Kabiliyeti & $200 \mathrm{~km} / 10$ saniye \\
\hline Uydu Üzerinde Depolama & 2199 GB' l1k yarı iletken disk \\
\hline İletişim & $\begin{array}{l}\text { Görüntü ve Yardımcı Veri: X-bant } 800 \text { Mbps, } \\
\text { Kayıt Tutma: X-bant 4, 16, } 32 \text { kbps gerçek zamanlı; } 524 \text { kbps depolanmış } \\
\text { Uzaktan Kumanda: } 2 \text { ya da } 64 \text { kbps S-bant }\end{array}$ \\
\hline Uygulama Alanları & $\begin{array}{l}\text { İletişim, altyapı planlama haritaları ve ölçümü, mühendislik ve inşaat, koridor } \\
\text { haritalama, madencilik ve arama, petrol ve gaz, deniz ve kıyı ölçümleri, güncel ve } \\
\text { dünya olayları, turizm }\end{array}$ \\
\hline Elde Edilen Ürünler & $\begin{array}{l}\text { DEM, DTM, DSM } \\
\text { Temel(Ham)Görüntü, Orto-Hazır Görüntü } \\
\text { Ortorektifiye edilmiş Görüntü } \\
\text { Geo, GeoStereo, GeoTIFF }\end{array}$ \\
\hline
\end{tabular}

Tablo 5. Worldview-2 uydusunun tasarım ve teknik özellikleri (URL 11)

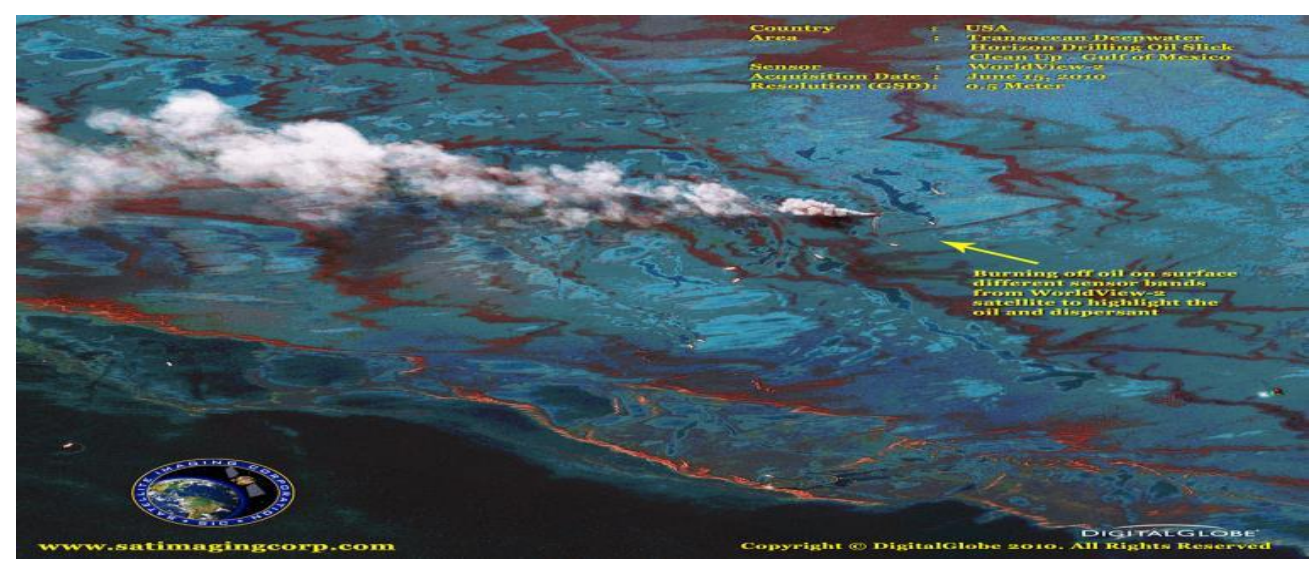

Şekil 7. Worldview-2 uydu görüntüsü örneği (deniz ve kıyı ölçmeleri) (URL 18) 


\begin{tabular}{|c|c|}
\hline \multicolumn{2}{|r|}{ TASARIM VE TEKNIK ÖZELLİKLERİ } \\
\hline Firlatılma Bilgileri & $\begin{array}{l}\text { Tarih: } 13 \text { Ağustos } 2014 \\
\text { Yörünge Yerleştirme Aracı: Atlas V } \\
\text { Firlatma Yeri: Vandenberg Hava Üssü, California }\end{array}$ \\
\hline Yörünge & $\begin{array}{l}\text { Yükseklik: } 617 \mathrm{~km} \\
\text { Tür: Güneş uyumlu, alçalan düğüm noktasından 10:30, } \\
\text { Periyot: } 100 \text { dakika }\end{array}$ \\
\hline Görev Süresi & $10-12$ y1l \\
\hline Uzay Aracı Boyutu & $\begin{array}{l}\text { Boyut: } 5.7 \text { x } 2.5 \mathrm{~m} \text {, Ağırlık: } 2800 \mathrm{~kg}, 7.1 \mathrm{~m} \text { boyutlarında güneş paneli uzunluğu, } \\
3.1 \mathrm{~kW} \text { güneş enerjisi, } 100 \mathrm{Ahr} \text { batarya }\end{array}$ \\
\hline & $\begin{array}{l}\text { Pankromatik: } 0.31 \mathrm{~m}, 20^{\circ} \text { lik diş nadir açısında } 0.34 \mathrm{~m} \mathrm{GSD} \\
\text { Çok bantlı: } 1.24 \mathrm{~m}, 20^{\circ} \text { lik diş nadir açısında } 1.38 \mathrm{~m} \text { GSD }\end{array}$ \\
\hline $\begin{array}{l}\text { Mekansal ve Tayfsal } \\
\text { Çözünürlük }\end{array}$ & 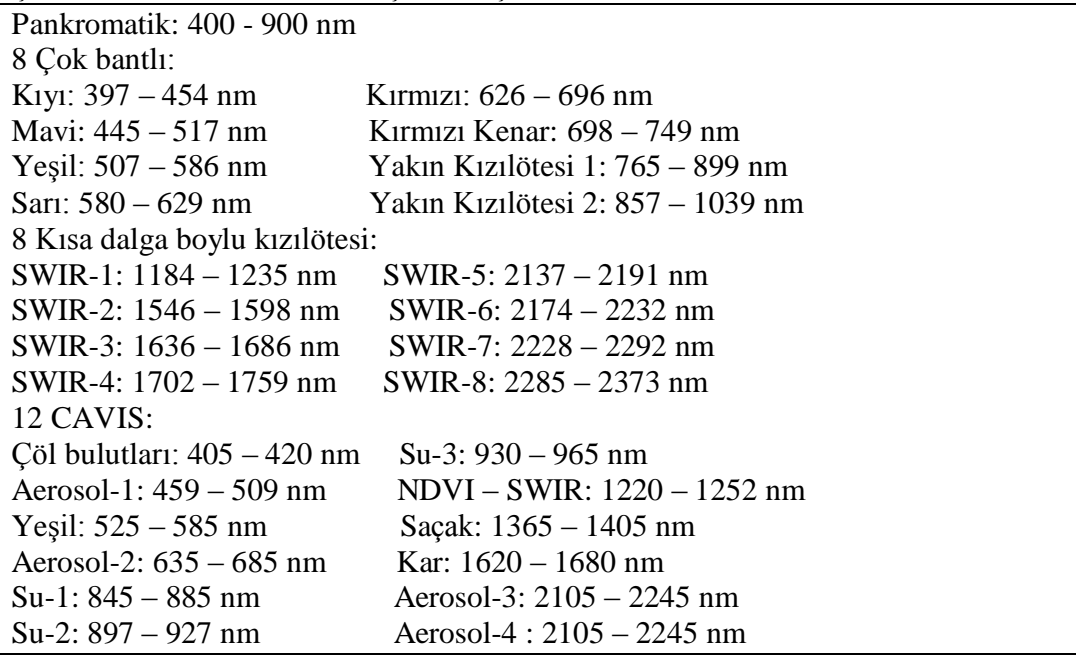 \\
\hline $\begin{array}{l}\text { Konumsal (Metrik) } \\
\text { Doğruluk }\end{array}$ & 3.5 m’ den küçük CE90 (Yer Kontrol Noktasız) \\
\hline Tarama Genişliği & \multirow{2}{*}{$\begin{array}{l}13.1 \mathrm{~km} \\
\text { Pan ve Cokbantl1: 11-bit(piksel basına), SWIR: 14-bit }\end{array}$} \\
\hline Dinamik Aralık & \\
\hline Konum Belirleme ve Kontrol & $\begin{array}{l}\text { Tür: } 3 \text { eksenli stabilize } \\
\text { Aktüatör: CMG } \\
\text { Algılayıcılar: Yıldız izleyici / Hassas IRU / GPS }\end{array}$ \\
\hline $\begin{array}{l}\text { Noktalama Doğruluğu ve } \\
\text { Bilgi }\end{array}$ & $\begin{array}{l}\text { Doğruluk: Görüntü başlama ve bitişlerinde }<500 \mathrm{~m} \\
\text { Bilgi: Coğrafi konum doğruluğunu destekler. }\end{array}$ \\
\hline $\begin{array}{l}\text { Tekrarlama Süresi } \\
\left(40^{\circ} \text { Enleminde }\right)\end{array}$ & $\begin{array}{l}1 \text { m GSD' de ya da daha az çözünürlükte } 1 \text { günden az } \\
20^{\circ} \text { ' lik diş nadir açısında } 4.5 \text { gün }\end{array}$ \\
\hline Toplama Kapasitesi & Günlük $680000 \mathrm{~km}^{2}$ \\
\hline $\begin{array}{l}\text { Tek Geçişte Sürekli } \\
\text { Toplanabilecek En Fazla } \\
\text { Alan }\end{array}$ & $\begin{array}{l}\text { Mono: } 66.5 \text { x } 112 \mathrm{~km} \text { (5 kolon) } \\
\text { Stereo: } 26.6 \text { x } 112 \mathrm{~km} \text { (2 çift) }\end{array}$ \\
\hline $\begin{array}{l}\text { Yeniden Hedefleme } \\
\text { Kabiliyeti }\end{array}$ & $200 \mathrm{~km} / 12$ saniye \\
\hline Uydu Üzerinde Depolama & 2199 GB' lik yarı iletken disk \\
\hline İletişim & $\begin{array}{l}\text { Görüntü ve Yardımcı Veri: X-bant } 800 \text { ve } 1200 \text { Mbps, } \\
\text { Kayıt Tutma: X-bant 4, 16, 32, } 64 \text { kbps gerçek zamanlı; } 524 \text { kbps depolanmış } \\
\text { Uzaktan Kumanda: } 2 \text { ya da } 64 \text { kbps S-bant'dan }\end{array}$ \\
\hline Uygulama Alanları & $\begin{array}{l}\text { Haritalama, Arazi sınıflandırma, Afete hazırlık / Tepki, Detay çıkarımı / Değişiklik } \\
\text { tespiti, Toprak / Bitki analizi, Jeoloji, petrol ve gaz, madencilik, Çevresel gözetleme, } \\
\text { Batımetri / Kıyı uygulamaları, Yapay malzemelerin belirlenmesi, Ormancılık, } \\
\text { Havacılık, Yabani hayatı izleme, Ulaşım, Spor ve Turizm }\end{array}$ \\
\hline Elde Edilen Ürünler & $\begin{array}{l}\text { DEM, DTM, DSM } \\
\text { Temel(Ham)Görüntü, Orto-Hazır Görüntü } \\
\text { Ortorektifiye edilmiş Görüntü } \\
\text { Geo, GeoStereo, GeoTIFF }\end{array}$ \\
\hline
\end{tabular}

Tablo 6. Worldview-3 uydusunun tasarım ve teknik özellikleri (URL 12) 


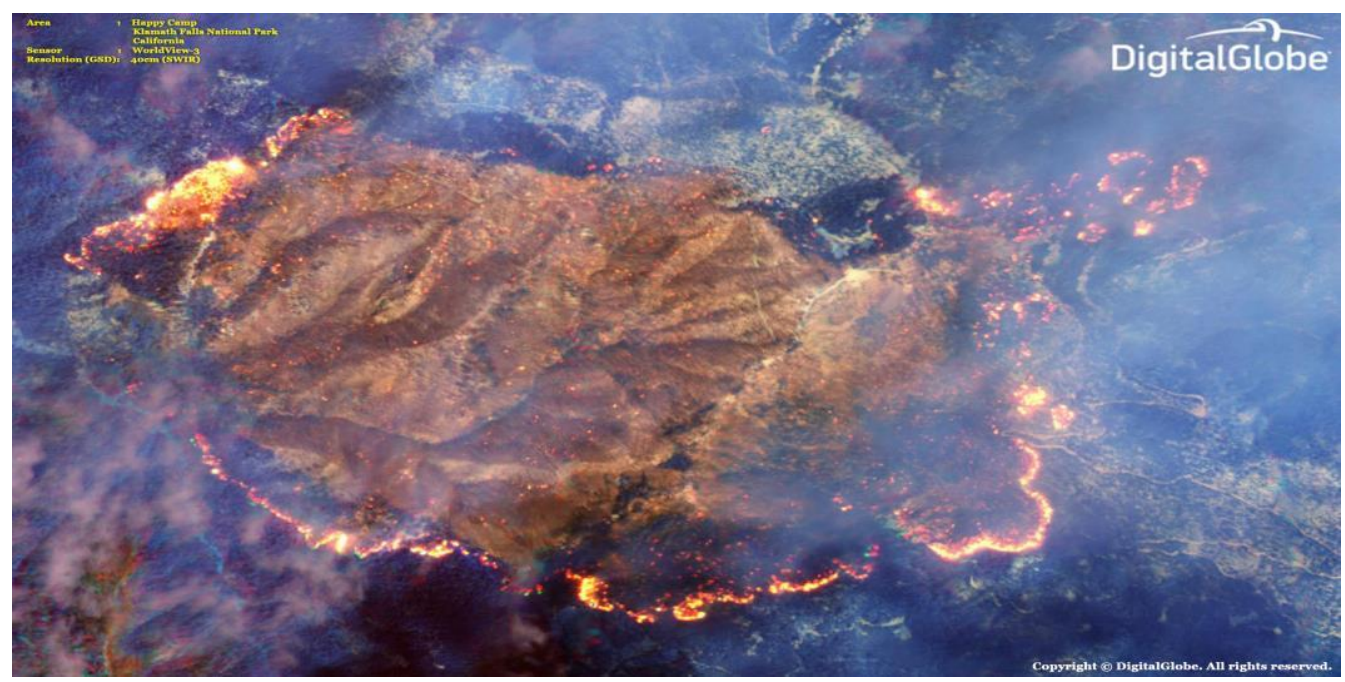

Şekil 8. Worldview-3 uydu görüntüsü örneği (ormancılık) (URL 19)

\begin{tabular}{|c|c|}
\hline \multicolumn{2}{|r|}{ TASARIM VE TEKNIKK ÖZELLIKLERİ } \\
\hline Firlatılma Bilgileri & $\begin{array}{l}\text { Tarih: } 11 \text { Kasım } 2016 \\
\text { Yörünge Yerleştirme Aracı: Atlas V } \\
\text { Fırlatma Yeri: Vandenberg Hava Üssü, California }\end{array}$ \\
\hline Yörünge & $\begin{array}{l}\text { Yükseklik: } 617 \mathrm{~km} \\
\text { Tür: Güneş uyumlu, alçalan düğüm noktasından 10:30, } \\
\text { Periyot: } 97 \text { dakika }\end{array}$ \\
\hline Görev Süresi & $10-12$ y1l \\
\hline Uzay Aracı Boyutu & $\begin{array}{l}\text { Boyut: } 5.3 \text { x } 2.5 \mathrm{~m} \text {, Ağırlık: } 1898 \mathrm{~kg} 7.9 \mathrm{~m} \text { boyutlarında güneş paneli } \\
\text { uzunluğu, Çap: } 1.1 \mathrm{~m}\end{array}$ \\
\hline \multirow{2}{*}{ Mekansal ve Tayfsal Çözünürlük } & $\begin{array}{l}\text { Pankromatik: } 0.31 \mathrm{~m} \text { GSD } \\
\text { Çok bantlı: } 1.24 \mathrm{~m} \text { GSD } \\
\end{array}$ \\
\hline & $\begin{array}{l}\text { Pankromatik: } 450 \text { - } 800 \mathrm{~nm} \\
\text { Çok bantlı: Mavi: } 450 \text { - } 510 \mathrm{~nm} \text {, Yeşil: 510-580 nm, Kırmızı: 655-690 nm } \\
\text { Yakın Kızılötesi: } 780 \text { - } 920 \mathrm{~nm}\end{array}$ \\
\hline Konumsal (Metrik) Doğruluk & 3.5 m’ den küçük CE90 (Yer Kontrol Noktası) \\
\hline Tarama Genişliği & $13.1 \mathrm{~km}$ \\
\hline Dinamik Aralık & Piksel başına 11-bit \\
\hline Konum Belirleme ve Kontrol & $\begin{array}{l}\text { Tür: } 3 \text { eksenli stabilize } \\
\text { Algılayıcılar: Yıldız izleyici / Hassas IRU /GPS }\end{array}$ \\
\hline Tekrarlama Süresi $\left(40^{\circ}\right.$ Enleminde $)$ & 1 m GSD' de 1 günden az \\
\hline Toplama Kapasitesi & Günlük $680000 \mathrm{~km}^{2}$ \\
\hline $\begin{array}{l}\text { Tek Geçişte Sürekli Top. En Fazla } \\
\text { Alan }\end{array}$ & Mono: 66.5 x 112 km (5 kolon) Stereo: 26.6 x 112 km (2 çift) \\
\hline Yeniden Hedefleme Kabiliyeti & $200 \mathrm{~km} / 10.6$ saniye \\
\hline Uydu Üzerinde Depolama & 3200 GB yarı iletken disk \\
\hline İletişim & $\begin{array}{l}\text { Görüntü ve Yardımcı Veri: X-bant } 800 \mathrm{Mbps} \\
\text { Kayıt Tutma: X-bant } 1200 \text { kbps gerçek zamanlı } \\
\text { Uzaktan Kumanda: } 64 \text { kbps S-bant }\end{array}$ \\
\hline Uygulama Alanları & $\begin{array}{l}\text { Haritalama, Arazi sınıflandırma, Afete hazırlık / Tepki, Detay çıkarımı / } \\
\text { Değişiklik tespiti, Toprak / Bitki analizi, Jeoloji, petrol ve gaz, } \\
\text { madencilik, Çevresel gözetleme, Batımetri / Kıyı uygulamaları, Yapay } \\
\text { malzemelerin belirlenmesi, Ormancılık, Havacılık, Yabani hayatı izleme, } \\
\text { Ulaşım, Turizm }\end{array}$ \\
\hline Elde Edilen Ürünler & $\begin{array}{l}\text { DEM, DTM, DSM } \\
\text { Temel(Ham)Görüntü, Orto-Hazır Görüntü } \\
\text { Ortorektifiye edilmiş Görüntü } \\
\text { Geo, GeoStereo, GeoTIFF }\end{array}$ \\
\hline
\end{tabular}

Tablo 7. Worldview-4 uydusunun tasarım ve teknik özellikleri (URL 13) 


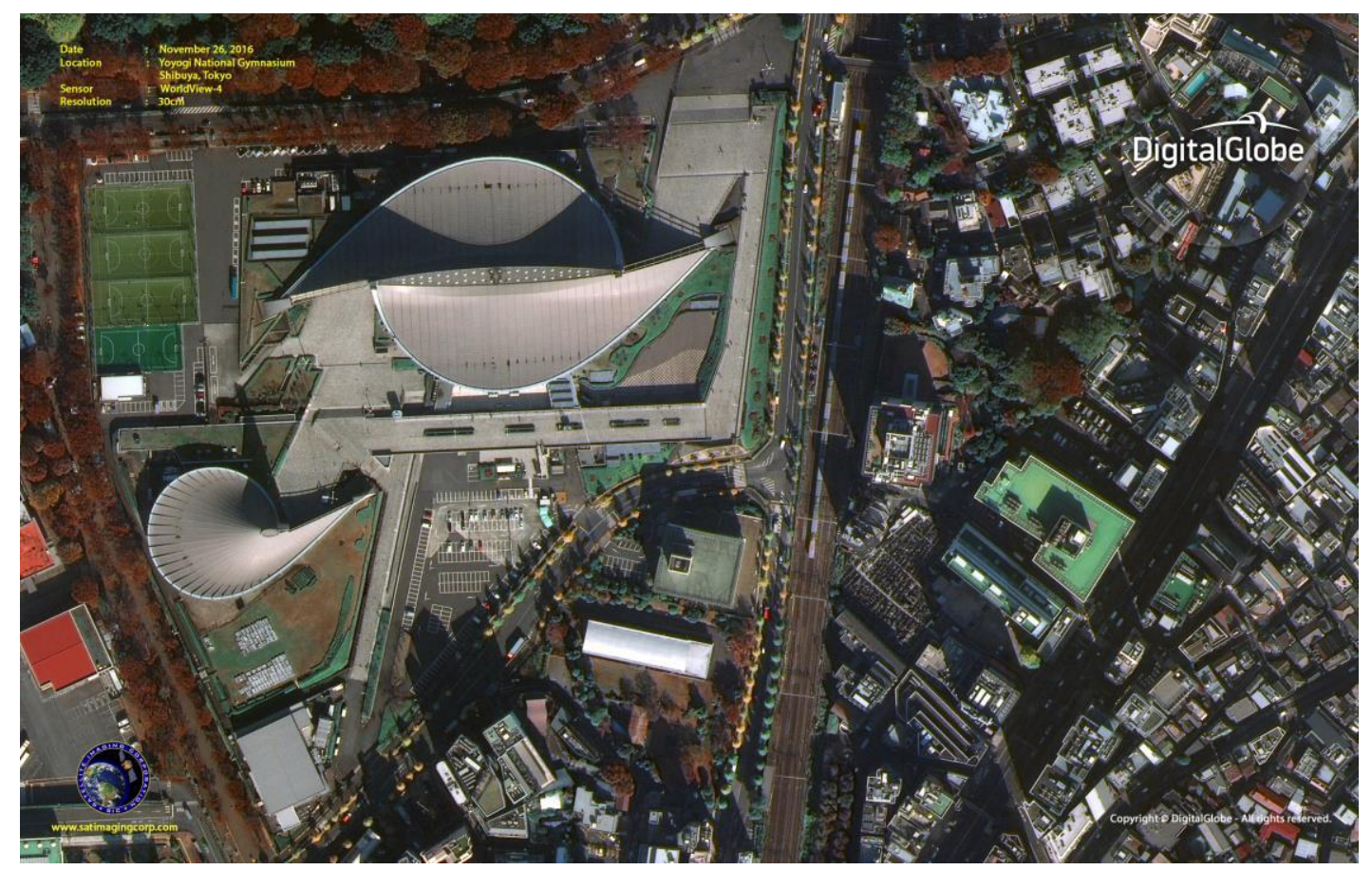

Şekil 9. Worldview-4 uydusunun ilk görüntüsü (URL 20)

\begin{tabular}{|c|c|c|c|c|c|c|c|}
\hline \multicolumn{8}{|c|}{ ÖZELLİKLER } \\
\hline Uydular & Ikonos & Quickbird & Geoeye-1 & Worldview-1 & Worldview-2 & Worldview-3 & Worldview-4 \\
\hline Yükseklik & $681 \mathrm{~km}$ & $450 \mathrm{~km}$ & $681 \mathrm{~km}$ & $496 \mathrm{~km}$ & $770 \mathrm{~km}$ & $617 \mathrm{~km}$ & $617 \mathrm{~km}$ \\
\hline Gsd (pan) & $0.82 \mathrm{~m}$ & $0.61 \mathrm{~m}$ & $0.41 \mathrm{~m}$ & $0.50 \mathrm{~m}$ & $0.46 \mathrm{~m}$ & $0.31 \mathrm{~m}$ & $0.31 \mathrm{~m}$ \\
\hline Gsd (ms) & $3.2 \mathrm{~m}$ & $2.44 \mathrm{~m}$ & $1.65 \mathrm{~m}$ & - & $1.85 \mathrm{~m}$ & $1.24 \mathrm{~m}$ & $1.24 \mathrm{~m}$ \\
\hline $\begin{array}{c}\text { Tarama } \\
\text { Genişliği }\end{array}$ & $11.3 \mathrm{~km}$ & $16.8 \mathrm{~km}$ & $15.3 \mathrm{~km}$ & $17.7 \mathrm{~km}$ & $16.4 \mathrm{~km}$ & $13.1 \mathrm{~km}$ & $13.1 \mathrm{~km}$ \\
\hline Toplama & 240000 & 200000 & 350000 & 1300000 & 1000000 & 680000 & 680000 \\
\hline Kapasitesi & $\mathrm{km}^{2}$ & $\mathrm{~km}^{2}$ & $\mathrm{~km}^{2}$ & $\mathrm{~km}^{2}$ & $\mathrm{~km}^{2}$ & $\mathrm{~km}^{2}$ & $\mathrm{~km}^{2}$ \\
\hline $\begin{array}{l}\text { Ortalama } \\
\text { Tekrarlama } \\
\text { Süresi }\end{array}$ & 3 gün & 2.4 gün & 2.6 gün & 1.7 gün & 1.1 gün & $\leq 1$ gün & $<1$ gün \\
\hline & PAN & PAN & PAN & & PAN & $\mathrm{PAN}+8 \mathrm{MS}$ & PAN \\
\hline Rantlar & + & + & + & PAN & + & + & + \\
\hline & MS & $4 \mathrm{MS}$ & $4 \mathrm{MS}$ & & $8 \mathrm{MS}$ & 8 SWIR+12 CAVIS & $4 \mathrm{MS}$ \\
\hline $\begin{array}{c}\text { Doğruluk } \\
\text { (CE90) }\end{array}$ & $9 \mathrm{~m}$ & $23 \mathrm{~m}$ & $3 \mathrm{~m}$ & $<4 \mathrm{~m}$ & $<3.5 \mathrm{~m}$ & $<3.5 \mathrm{~m}$ & $<4 \mathrm{~m}$ \\
\hline
\end{tabular}

Tablo 8. Uyduların önemli özelliklerinin karşılaştırılması 